\title{
Computational Studies of Horizontal Axis Wind Turbines Using Advanced Turbulence Models
}

\author{
Sebit KODY *, Emre ALPMAN and Barıș YILMAZ \\ Marmara University, Faculty of Engineering, Department of Mechanical Engineering, 34722, Kadıköy, İstanbul
}

\section{Özet}

$\mathrm{Bu}$ çalışma kapsamında NREL faz II yatay eksenli, rüzgara karşı (downwind) bir rüzgar türbininin aerodinamik ve performans karakteristiği, ticari FLUENT ${ }^{\circledR}$ Hesaplamalı Akışkanlar Dinamiği (HAD) yazılımıyla modellenerek araştırılması amaçlanmaktadır. Kullanılan HAD analiz programı çözümü uzayda üçüncü dereceden, zamanda ikinci dereceden hassas, kapalı çözüm tekniği ve zaman-adımı şeması (time-marching scheme) kullanmaktadır.Bu calismada, Spalart-Allmaras (S-A), Standart k- $\varepsilon$, RNG- k- and SST k- $\omega$ modelleri olmak üzere dört farklı türbülans modeli kullanılmış ve sonuçlar değerlendirilmiştir. Modellenen rüzgar türbinine ait sayısal çözümle elde edilen sonuçlar, literatürde yer alan deneysel sonuçlarla karşılaştırılmıştır. Çözümleyici için iki milyon hücreli düzenli olmayan ağ yapisi GAMBIT programı kullanılarak oluşturulmuştur. Karşılaştırmalar HAD modellemesinin ile kanadın bir ucundan diğer ucuna oluşan kuvveti kabul edilebilir bir hata ile tahmin edebildiğini göstermiştir.

Anahtar Kelimeler: Rüzgar türbini, NREL Faz II, türbülans modelleri, basınç katsayısı, dönme momenti, HAD.

\begin{abstract}
The work presented in this paper aims to study the aerodynamic characteristics and performance of the NREL phase II rotor that is a horizontal axis upwind wind turbine rotor using a commercial 3-D Navier-Stokes solver FLUENT ${ }^{\circ}$. This solver is third order accurate in space and second order accurate in time, and uses an implicit time marching scheme. In this study, four turbulence models including Spalart-Allmaras (S-A), Standard k- $\varepsilon$, RNG- k- $\epsilon$ and SST k- $\omega$ models were used and evaluated. These models are considered to be the work horses of the turbulence modeling literature. The numerical results for considered wind turbine rotor were compared to the available experimental data.

An unstructured grid of approximately 2 million cells is generated using the GAMBIT software, was used in computations. The comparisons show that CFD results along with the turbulence models used can predict the span-wise loading of the wind turbine rotor with reasonable agreement.
\end{abstract}

Keywords: Wind turbine, NREL Phase II, turbulence model, blade torque, computational fluid Dynamics CFD.

\section{1-Introduction}

Numerical solution of flows through wind turbines is increasingly useful since it helps reduce time and cost in wind turbine development. The flow around a rotating wind turbine blades is mainly unsteady, three-dimensional and turbulent [1], with the whole or part of the blade very often operating under stall conditions. Thus turbulence model is increasingly important in numerical analysis of the horizontal axis wind turbine. Turbine blades may experience 
complex phenomena like changes in angle of attack due to inflow turbulence, dynamic stall, unsteady loads, etc, which considerably affect turbine performance, blade elasticity and acoustics [2-4]. The vortex and turbulence dynamics in the wake can be especially important for rotor-stator interactions, or wind turbine farms [5-7]. Hence it becomes very important to accurately predict the turbulent flow around turbines.

Navier-Stokes methodologies demonstrate promise in capturing aerodynamics at the blade stall but wake effects, flow unsteadiness and grid resolution have constrained its accuracy.

In general, there is no single turbulence model to be universally accepted as being superior for all classes of problems. The choice of turbulence model will depend on considerations such as the physics encompassed in the flow, the established practice for a specific class of problem. Flow pass an untwisted Horizontal Axis Wind Turbine (HAWT) blade is too much complex since it combined of axial inflow velocity at the rotor plane the inflow velocity caused by the rotation of the blade, and the inflow velocity caused by wake rotation at the rotor plane. In addition, centrifugal force acting along the blade due to the rotation of the blade causes a flow along the span [8-9].

Wind speed is constant and as blade radius increases along the span of blade then annular velocity, $r w$, increases linearly. So, the angle of attack changes too and this causes a change in lift and drag orientation. When the angle of attack becomes large the flow over the blade begins to separate and a condition known as stall occurs. $[9,10]$. Stall causes a sudden decrease in lift force and a sudden increase in drag force. Hence it negatively affects the power produced by the turbine.

Another issue involved with numerical flow simulation around a HAWT blade is grid generation. In this study an unstructured mesh was constructed around one of the blades of the three-bladed turbine. Because of the relatively complex flow domain, constructing an unstructured mesh with triangular cells near the blade surface provides more an efficient way to generate three-dimensional mesh. Unstructured mesh also allows controlling the fineness of the mesh at the desired locations. In this study, the rotating wind turbine modeled with rotating reference frame instead of dynamic grid so the model could be solved steadily $[10,11]$.

The aim of this work is to perform a 3-D flow simulation for the three-bladed NREL Phase II wind turbine [12] with the aid of a commercially available CFD package FLUENT. Several 3-D simulations were carried out to yield information on different aspects involved, ranging from aerodynamic calculations to wake development. The numerical results for the considered wind turbine rotor are compared to experimental data [12] for validation purposes; another objective of the present research is to draw conclusions on the adequacy of these numerical results.

\section{2-Turbine Geometry}

In this study, available test data for the NREL Phase II Wind Turbine [12,13] was used to validate the numerical results The blades had, NREL S809 airfoil profile, which was shown in Figure.1. The NREL S809 airfoil series is used, except for the location close to the root. At $14.4 \%$ span the airfoil thickness is $\mathrm{t} / \mathrm{c}=43 \%$ and it decreases linearly to $\mathrm{t} / \mathrm{c}=20.95 \%$ at $30 \%$ span, while outboard of $30 \%$, thickness is constant at that value. The rotor had a radius of $5.029 \mathrm{~m}$, and the geometry constructed for numerical solutions were shown in figures $2 \mathrm{a}$. and $2 \mathrm{~b}$. The blade of the phase-II rotor had a constant rotation of $72 \mathrm{rpm}$ and a $20 \mathrm{~kW}$ of rated power. The blade pitch angle was constant $12^{\circ}$ and blade has no twist and was non-tapered with a constant cord of $0.4572 \mathrm{~m}[11,12,13]$. 


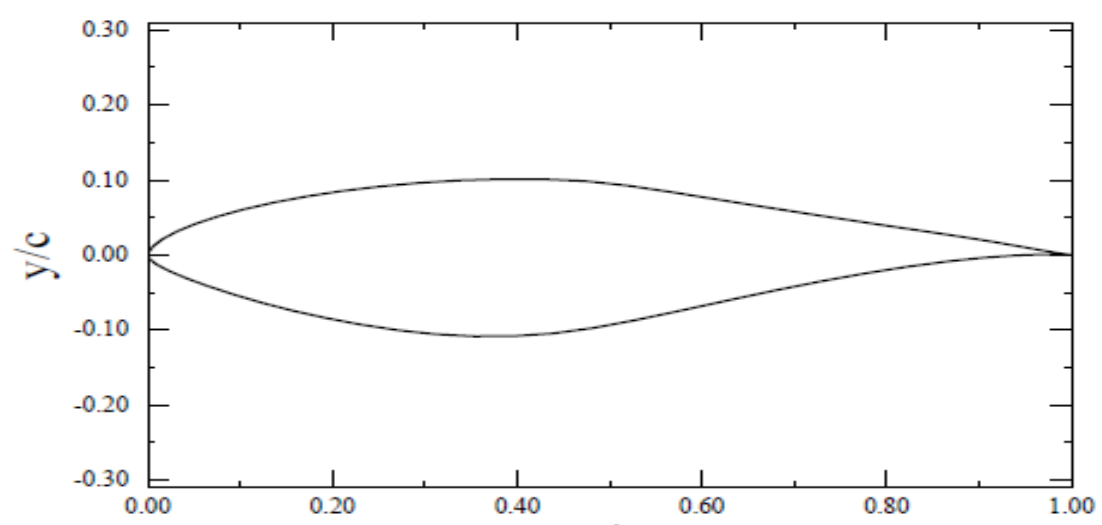

Fig. 1. NREL S809 Airfoil Profile [12]

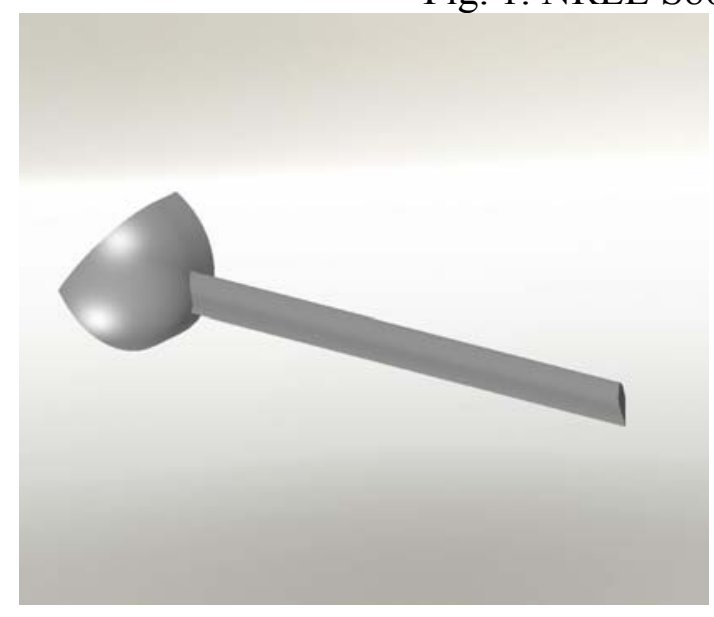

Fig. 2a. Hub and turbine blade geometry $(1 / 3$ periodic model)

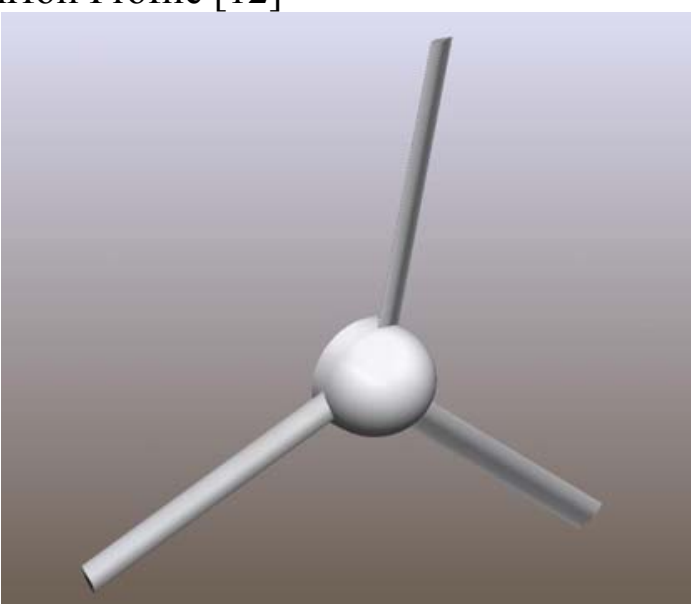

Fig. 2b. Three blades assembled

\section{Mathematical and Numerical Models}

\subsection{Reynolds Averaged Navier Stokes (RANS) Equations}

The mathematical modeling of the complicated HAWT rotor flow as provided by the Reynolds Averaged Navier-Stokes (RANS) equations [15, 16]. These equations are timeaveraged equations of fluid flow and they are primarily used while dealing with turbulent flows. These equations combined with a suitable turbulence model gives approximate average solutions to the Navier-Stokes equations. The RANS equations can be written in Cartesian tensor form as:

$$
\begin{gathered}
\frac{\partial \rho}{\partial t}+\frac{\partial}{\partial x_{i}}\left(\rho u_{i}\right)=0 \\
\frac{\partial}{\partial t}\left(\rho u_{i}\right)+\frac{\partial}{x_{i}}\left(\rho u_{i} u_{j}\right)=-\frac{\partial \rho}{\partial x_{i}}+\frac{\partial}{\partial x_{j}}\left[\mu\left(\frac{\partial u_{i}}{\partial x_{i}}+\frac{\partial u_{j}}{\partial x_{j}}-\frac{2}{3} \delta_{i j} \frac{\partial u_{i}}{\partial x_{j}}\right)\right]+\frac{\partial}{\partial x_{i}}\left(-\rho \overline{u_{\imath}^{\prime} u_{j}^{\prime}}\right)
\end{gathered}
$$

Where the velocities and other solution variables now representing ensemble-averaged (or time-averaged) values [16].

\subsection{Turbulence Models}

The governing equations, of the four turbulence models that were used in numerical solutions, were explained below.

\subsubsection{Spalart-Allmaras Turbulence Model}


In Spalart-Allmaras model, the simple algebraic eddy viscosity model is replaced with a phenomenological one-equation eddy viscosity model [17].

In this model, the Reynolds stresses are given by:

$$
-\overline{u_{\imath} u_{\jmath}}=2 v_{t} S_{i j}
$$

Where

$$
S_{i j}=\frac{1}{2}\left(\frac{\partial U_{i}}{\partial x_{j}}+\frac{\partial U_{j}}{\partial x_{i}}\right)
$$

The eddy viscosity $v_{t}$ is given by

$$
v_{t}=\breve{v} f_{v 1}
$$

Where,

$$
f_{v 1}=\frac{X^{3}}{X^{3}+C_{v 1}^{3}} \quad \text { and, } \quad X \equiv \frac{\check{v}}{v}
$$

Here $v$ is the molecular viscosity. The quantity $\widetilde{v}$ is the working variable and obeys the transport equation.

$$
\begin{gathered}
\frac{D \tilde{v}}{D t}=c_{b 1}\left[1-f_{t 2}\right] \tilde{S} \tilde{v}+\frac{1}{\sigma}\left[\nabla \cdot((v+\tilde{v}) \nabla \tilde{v})+c_{b 2}(\nabla \tilde{v})^{2}\right] \\
-\left[c_{w 1} f_{w}-\frac{c_{b 1}}{k^{2}} f_{t 2}\right]\left[\frac{\tilde{v}}{d}\right]^{2}+f_{t 1} \Delta U^{2}
\end{gathered}
$$

For further details about the Spalart-Allmaras model and the model constants see reference [17].

\subsubsection{Standard k- $\varepsilon$ model}

The simplest "complete models" of turbulence are the two-equation models in which the solution of two separate transport equations allows the turbulent velocity and length scales to be independently determined. The standard k- $\varepsilon$ model falls within this class of models.

It is the most widely used model but it cannot predict flow separation accurately because it neither integrates up to the wall nor does it account for modification of turbulence dissipation due to an adverse pressure gradient.

The standard k- $\varepsilon$ model is a semi-empirical model based on model transport equations for the turbulence kinetic energy $(\mathrm{k})$ and its dissipation rate $(\varepsilon)$. The model transport equation for $\mathrm{k}$ is derived from the exact equation, while the model transport equation for $\boldsymbol{\varepsilon}$ was obtained using physical reasoning and bears little resemblance to its mathematically exact counterpart. In the derivation of the $\mathrm{k}-\boldsymbol{\varepsilon}$ model, the assumption is that the flow is fully turbulent, and the effects of molecular viscosity are negligible. The standard $\mathrm{k}-\boldsymbol{\varepsilon}$ model is therefore valid only for fully turbulent flows $[18,19]$. 


$$
\begin{gathered}
\frac{\partial}{\partial t}(\rho k)+\nabla \cdot(\rho k U)=\nabla \cdot\left[\left(\mu+\frac{\mu_{t}}{\sigma_{k}}\right) \nabla k\right]+\tau_{i j} \nabla U-\rho \varepsilon \\
\frac{\partial}{\partial t}(\rho \varepsilon)+\nabla \cdot(\rho \varepsilon U)=\nabla \cdot\left[\left(\mu+\frac{\mu_{t}}{\sigma_{\varepsilon}}\right) \nabla \varepsilon\right]+C_{1 \varepsilon} \frac{\varepsilon}{k} \tau_{i j} \nabla U-C_{2 \varepsilon} \rho \frac{\varepsilon^{2}}{k}
\end{gathered}
$$

Where, $\tau_{i j}$ is the Reynolds stress tensor. By applying the Boussinesq's hypothesis,$\tau_{i j}$ is the linearly related to the mean flow strain tensor.

$$
\tau_{i j}=\mu_{t}\left[\nabla U+(\nabla U)^{T}-\left(\frac{2}{2} \nabla U\right) \mathrm{I}\right]+\frac{2}{2} \rho k I
$$

The turbulence (or eddy viscosity) $\mu_{t}$ is computed the combining $\mathrm{k}$ and $\varepsilon$ as follows

$$
\mu_{t}=\rho C_{\mu}\left(\frac{k^{2}}{\varepsilon}\right)
$$

For the Standard k- $\boldsymbol{\varepsilon}$ model constants were determined from the experimental data in reference [18].

\subsubsection{The RNG k- $\varepsilon$ model}

The RNG k- $\boldsymbol{\varepsilon}$ model was derived using a statistical technique called renormalization group theory. It is similar in form to the standard $\mathrm{k}-\varepsilon$ model, but it accurate and reliable for a wider class of flows than the standard k- $\varepsilon$ model. And also the RNG model is more responsive to the effects of rapid strain and streamlines curvature than the standard k- $\varepsilon$ model [18] Governing equation for transport equation $\mathrm{k}$ and $\varepsilon$ are :

$$
\begin{gathered}
\frac{\partial}{\partial t}(\rho k)+\nabla \cdot(\rho k U)=\nabla \cdot\left[\left(\alpha_{k} \mu_{e f f} \nabla k\right]+\tau_{i j} \nabla U-\rho \varepsilon\right. \\
\frac{\partial}{\partial t}(\rho \varepsilon)+\nabla \cdot(\rho \varepsilon U)=\nabla \cdot\left[\left(\alpha_{\varepsilon} \mu_{e f f} \nabla \varepsilon\right]+C_{1 \varepsilon} \frac{\varepsilon}{k} \tau_{i j} \nabla U-C_{2 \varepsilon} \rho \frac{\varepsilon^{2}}{k}-R_{\varepsilon}\right.
\end{gathered}
$$

$\tau_{i j}$ and $\mu_{t}$ are calculated as Standard k- $\varepsilon$ model in equation (9), (10).

The RNG $\mathrm{k}-\boldsymbol{\varepsilon}$ model and it is constant were explained clear in [18].

\subsubsection{The SST k- $\omega$ model}

The SST k- $\omega$ is one of the two models proposed by Menter [17,18] in 1993. Both models aim to take advantage of both $\mathrm{k}-\varepsilon$ and $\mathrm{k}-\omega$. The $\mathrm{k}-\varepsilon$ is the most widely used two-equation model today; however, it over predicts the turbulence length scale in the near-wall region. This behavior, therefore, over predicts the shear stress that might delay or prevent the separation in the area of inverse pressure gradients.

The original k- $\omega$, based on the Wilcox 1988 model [18], has a different problem. It is very sensitive to freestream values that are specified outside the shear layer. It was found that the solution to the transport equations could deviate significantly with different values of $\omega$ in the far field.

The original $\mathrm{k}-\omega$ model is given by: 


$$
\begin{array}{r}
\frac{D \rho k}{D t}=\tau_{i j} \frac{\partial u_{i}}{\partial x_{j}}+\beta^{*} \rho \omega k+\frac{\partial}{\partial x_{j}}\left[\left(\mu+\sigma_{k 1} \mu_{t}\right) \frac{\partial k}{\partial x_{j}}\right] \\
\frac{D \rho \omega}{D t}=\frac{\gamma_{1}}{v_{t}} \tau_{i j} \frac{\partial u_{i}}{\partial x_{j}}-\beta_{1} \rho \omega^{2} k+\frac{\partial}{\partial x_{j}}\left[\left(\mu+\sigma_{\omega 1} \mu_{T}\right) \frac{\partial \omega}{\partial x_{j}}\right]
\end{array}
$$

The $\mathrm{k}-\varepsilon$ can be rewriten in the form of $\omega$ as:

$$
\begin{gathered}
\frac{D \rho k}{D t}=\tau_{i j} \frac{\partial u_{i}}{\partial x_{j}}+\beta^{*} \rho \omega k+\frac{\partial}{\partial x_{j}}\left[\left(\mu+\sigma_{k 1} \mu_{t}\right) \frac{\partial k}{\partial x_{j}}\right] \\
\frac{D \rho \omega}{D t}=\frac{\gamma_{1}}{v_{t}} \tau_{i j} \frac{\partial u_{i}}{\partial x_{j}}-\beta_{2} \rho \omega^{2} k+\frac{\partial}{\partial x_{j}}\left[\left(\mu+\sigma_{\omega 2} \mu_{T}\right) \frac{\partial \omega}{\partial x_{j}}\right]+2 \rho \sigma_{\omega 2} \frac{1}{\omega} \frac{\partial}{\partial x_{j}} \frac{\partial \omega}{\partial x_{j}}
\end{gathered}
$$

The constants of this models and the model equations can found in references $[17,18]$.

\section{4-Computational Domain and Grid}

In the current research work, the wind turbine tower and the ground effect were neglected, The diameter of the computational domain was chosen to be $5 \mathrm{R}$ ( $\mathrm{R}$ rotor radius) to eliminate far field effects. The domain is extended to $3 \mathrm{R}$ of the blade in upstream direction and $10 \mathrm{R}$ of the blade in the downstream direction for the rotor. Exploiting the 120 degrees periodicity of the three-bladed rotor, only one of the blades is explicitly modeled as shown in Fig.(3). All the simulations and calculations were carried out on an Intel (R) Core (TM)I7-2600CPU \&3.40GHz with 8GB RAM.

A uniform wind speed was assumed at the entrance of the domain as boundary condition. The nominal rotation speed was $72 \mathrm{rpm}$. The pressure outlet condition is applied to the exit of the flow domain. The Gambit pre-processor tool is used to create the volume mesh. One-third of the domain was meshed. First a grid independence procedure was tried then a size function was adapted to mesh the blade and the flow domain. The volume mesh and boundary conditions for the flow domain are shown in Figure3.

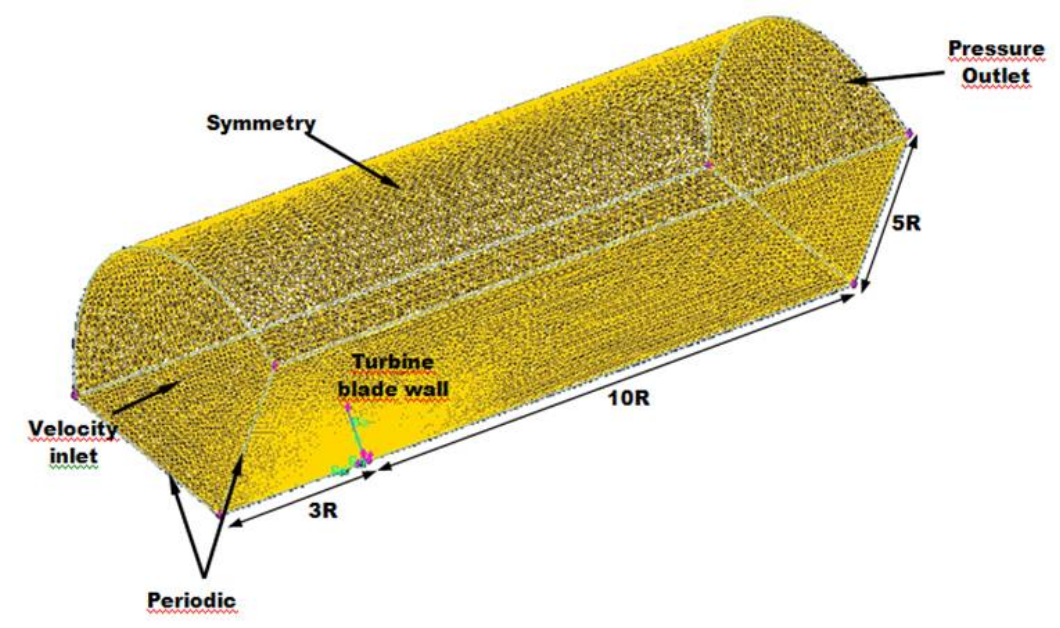

Fig. 3. The control volume meshing in 120 degrees section and definition of the boundary conditions for the flow domain. 
A size function was used to mesh both the blade and the flow domain. The unstructured (tetrahedral cell) grid volume mesh, with approximately 2 million cells, was generated. The cell-equiangle-skew and equivolume-skew were below 0.91 in the grid. Figures $4 \mathrm{a} \& 4 \mathrm{~b}$. show the grid of the phase II rotor blade and the mesh cut plane at blade. The unstructured mesh was generated on the blade with the Pave scheme. The blade surface and hub were covered with 141346 triangular cells.
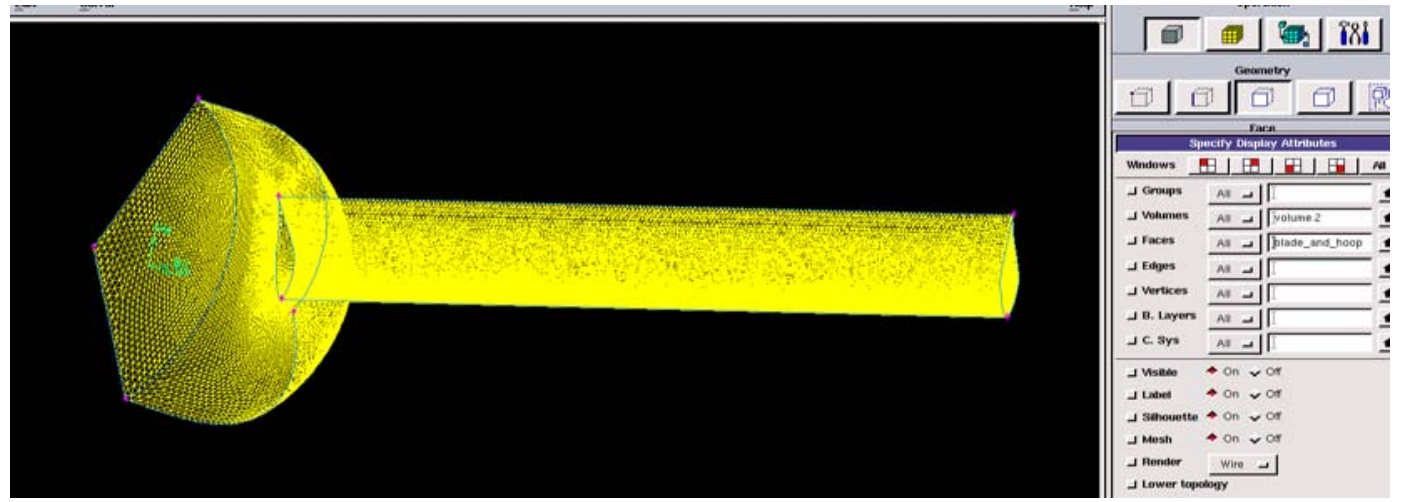

Fig.4a. The turbine blade face mesh
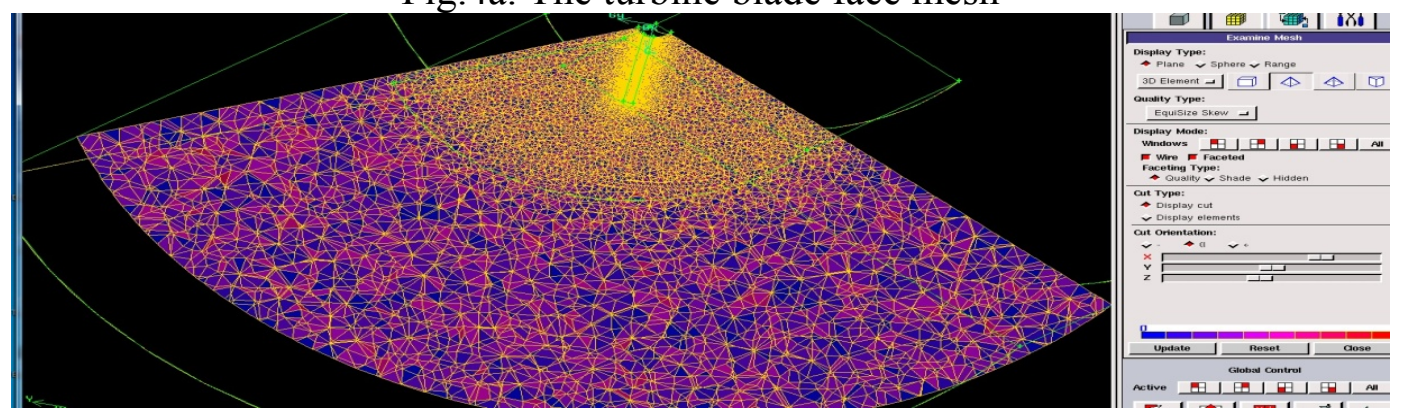

Fig.4b. Mesh cut plane at blade

\section{5-Methodology}

The computations were performed using the commercial software FLUENT[15,16].This CFD software solves the (RANS) equations with a selected turbulence model. The single blade, one-third, of the rotor was modeled and a periodic condition was imposed to account for the other two blades. The rotational axis was chosen to be $\mathrm{X}$-axis with the blade extending along the positive $\mathrm{Z}$ axis. The steady state simulation was done with an implicit, segregated, threedimensional solver using the Multiple Reference Frame (MRF) Model of FLUENT. The standard interpolation scheme for pressure was used. The second order upwind discretization scheme was used for the momentum and turbulence equations. The pressure velocity coupling was done with the SIMPLE technique [21]. The number of iterations adjusted to reduce the scaled residual below the value of $10^{-5}$ which is the criterion of convergence. For a typical run of a case the CPU time was approximately 48 hours (2days). The velocity inlet and pressure outlet boundary conditions of FLUENT are used for the inlet and outlet, respectively. The noslip boundary condition is assigned to the rotor blade surface. Four turbulence models including Spalart-Allmaras (S-A), Standard k- $\varepsilon$, RNG- k- $\epsilon$ and SST k- $\omega$ models were used and evaluated for rotor aerodynamic predictions[17,18]. The simulation is done at two uniform wind speeds of $7.2 \mathrm{~m} / \mathrm{s}$ and $10.56 \mathrm{~m} / \mathrm{s}$, as in NREL experiments, with fixed turbulence intensity and turbulence viscosity ratio for four turbulence models is used for the NREL phase II rotor blade [21, 22]. 


\section{6-Results and Discussion}

The predictions showed reasonably good agreement with experimental [13]. Figure.5a.\&5b. and Figure.6a.\&6b. show the comparison of computed pressure coefficients with experimental data at $30 \%$ and $80 \%$ span for $7.2 \mathrm{~m} / \mathrm{s}$ and $10.56 \mathrm{~m} / \mathrm{s}$.

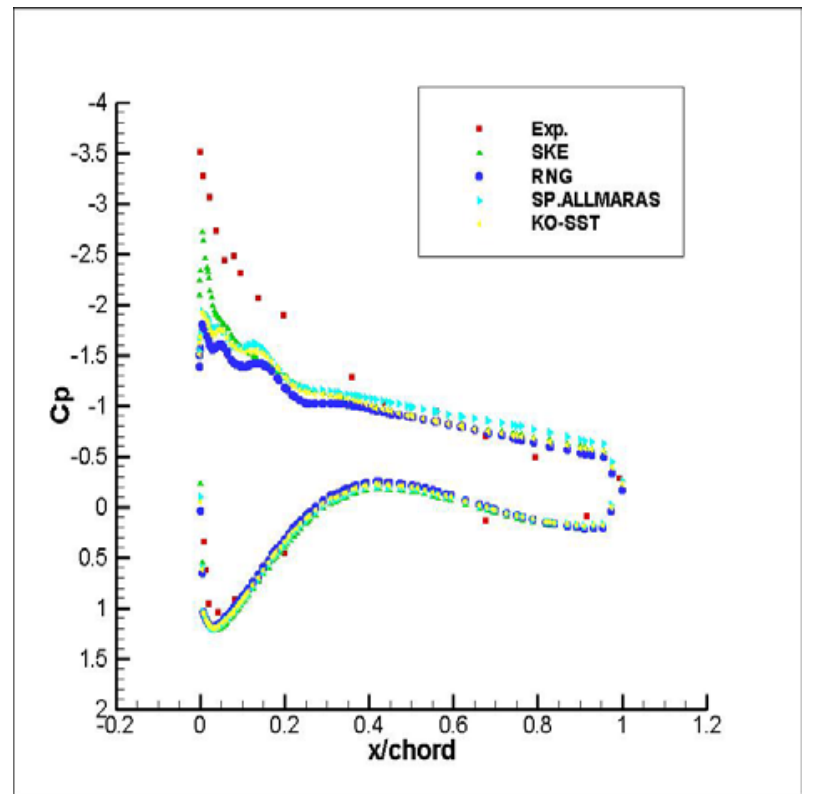

Fig. 5a. Pressure coefficient distributions at $\mathrm{r} / \mathrm{R}=0.30$ span. at $7.2 \mathrm{~m} / \mathrm{s}$

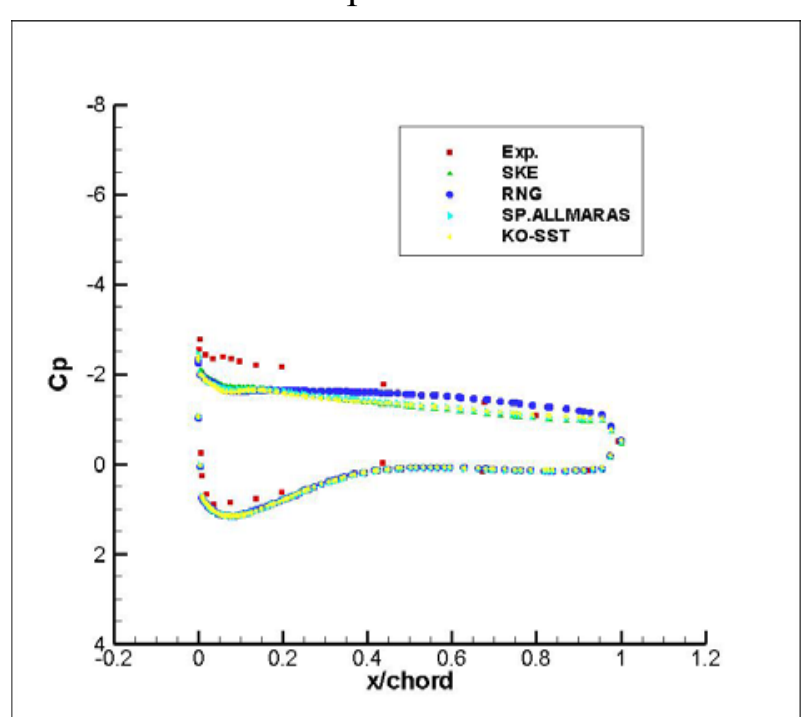

Fig. 6a. Pressure coefficient distributions at $\mathrm{r} / \mathrm{R}=0.30$ span. at $10.56 \mathrm{~m} / \mathrm{s}$

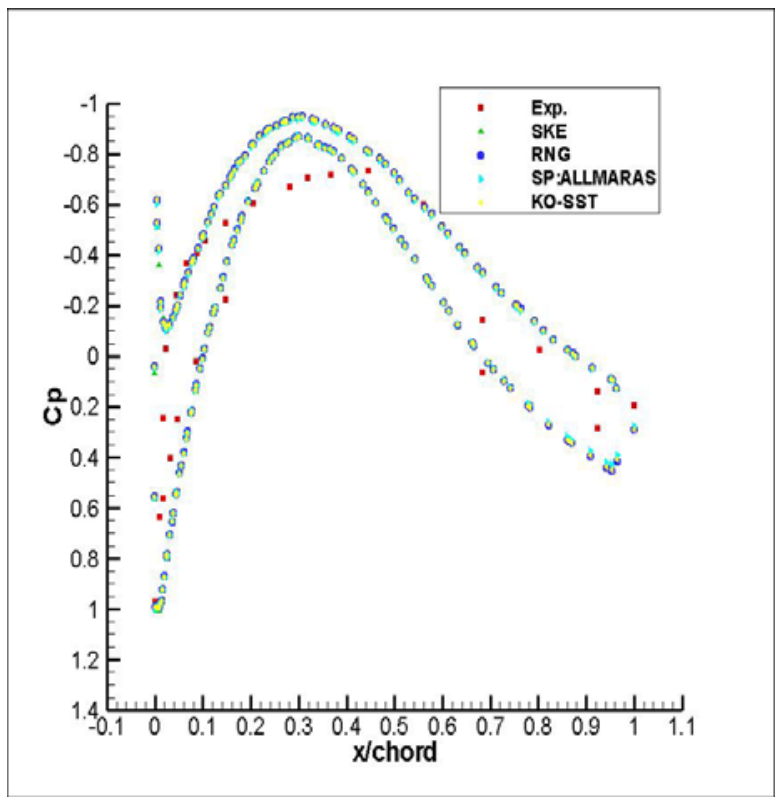

Fig. 5b. Pressure coefficient distributions at $\mathrm{r} / \mathrm{R}=0.80$ span. at $7.2 \mathrm{~m} / \mathrm{s}$

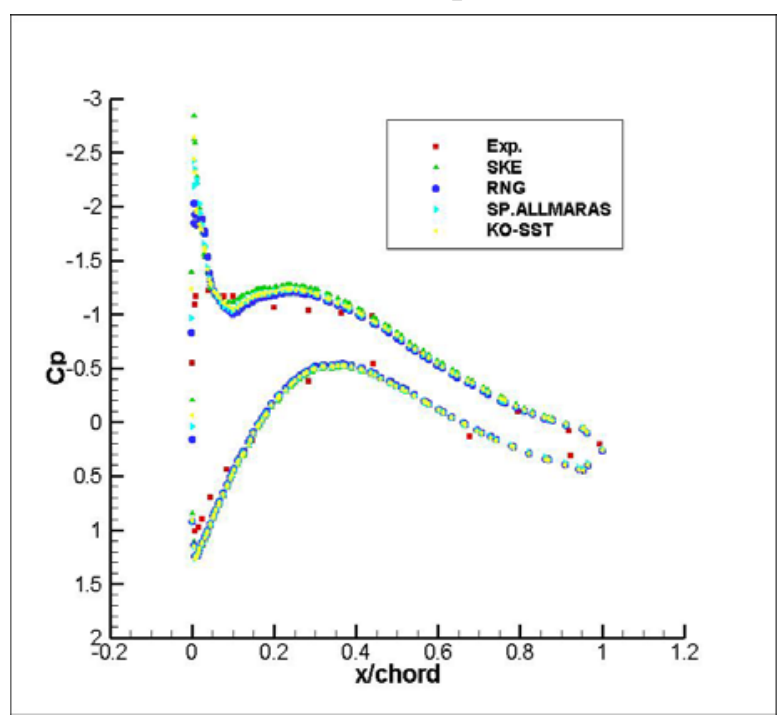

Fig. 6b. Pressure coefficient distributions at $\mathrm{r} / \mathrm{R}=0.80 \mathrm{span}$. at $10.56 \mathrm{~m} / \mathrm{s}$

The pressure coefficient is calculated using the following formula [20]:

$$
C_{p}=\frac{\left(\mathrm{P}_{\text {surface }}\right)+P_{\text {atm }}}{0.5 \rho\left(v^{2}+\omega^{2} r^{2}\right)}
$$

Where $\quad \mathrm{P}_{\text {surface }}=$ static pressure on the blade surface, $\mathrm{P}_{\mathrm{atm}}=$ atmospheric pressure

$$
\begin{aligned}
\mathrm{V} & =\text { the free stream wind, } & , \mathrm{C}_{\mathrm{P}} & =\text { pressure coefficient, } \\
\mathrm{r} & =\text { radius to reference part and } & \rho & =\text { air density }
\end{aligned}
$$


According to Figure $5 \mathrm{a} \& 5 \mathrm{~b}$, the predictions underestimated the pressure peak at the leading edge of the section. This was mainly because the stream wise grid not being fine enough to resolve that fast variation. A visible discrepancy between computations and measurements is also present over the mid parts of the $r / R=0.80$ section. Here, the measurements indicated a nearly flat pressure distribution which is an indication of flow separation and reattachment. This was clearly not captured by the computations.

Pressure predictions are in relatively better agreement with experiment for $10.56 \mathrm{~m} / \mathrm{s}$ wind speed at $\mathrm{r} / \mathrm{R}=0.30$ (Figure 6a). However, there is a clear discrepancy at the leading edge of $\mathrm{r} / \mathrm{R}=0.80$ section (Figure $6 \mathrm{~b}$ ). According to measurements, there is a laminar separation bubble at this location and it was not captured by any of the turbulence models. Inclusion of a laminar-to-turbulent transition model may fix this situation.

Figure 7a. and Figure $7 \mathrm{~b}$. show pressure contours around the turbine blade in $30 \%$ and $80 \%$ span, respectively. It was seen that the flow was attached to the blade in $80 \%$ but it has stall in $30 \%$ because of the high angle of attack in sections near the hub.

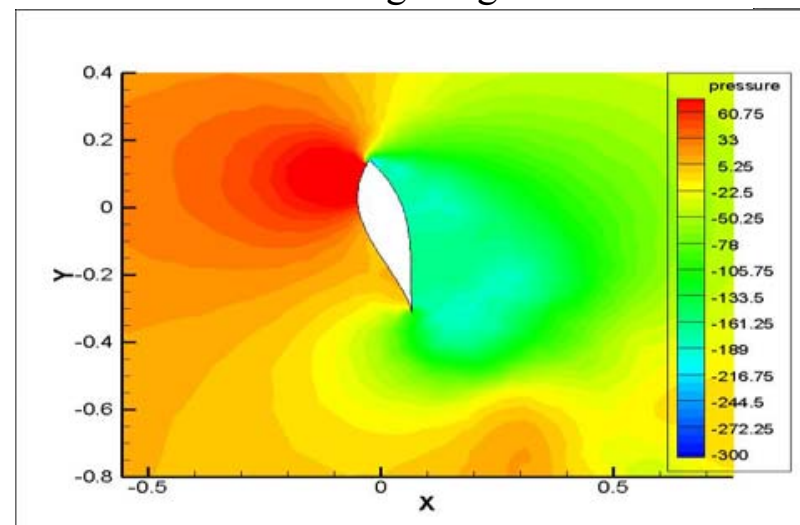

Fig.7a. Pressure contour in $30 \%$ span at $10.56 \mathrm{~m} / \mathrm{s}$ wind speed

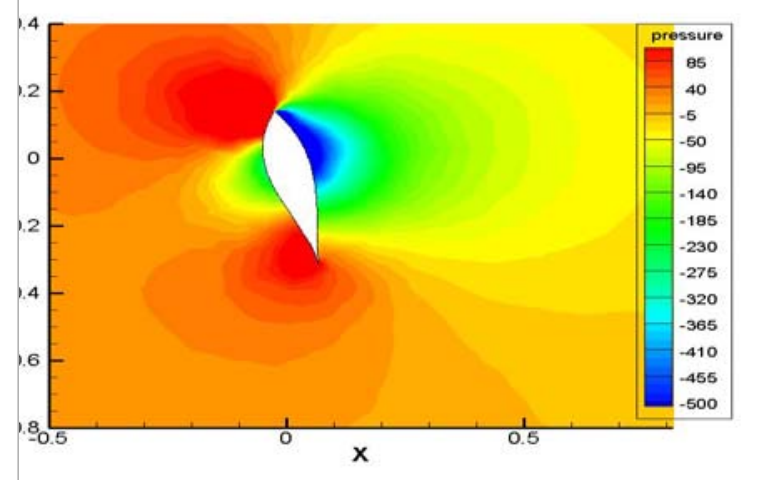

Fig. 7 b. Pressure contour in $80 \%$ span at $10.56 \mathrm{~m} / \mathrm{s}$ wind speed

The computed and measured torque results compared in Table $1 \& 2$ at wind speed $7.2 \mathrm{~m} / \mathrm{s}$ and $10.56 \mathrm{~m} / \mathrm{s}$ respectively:

Table 1. Comparison of computed and measured torque results wind speed at $7.2 \mathrm{~m} / \mathrm{s}$

\begin{tabular}{|c|c|c|c|}
\hline $\begin{array}{c}\text { Turbulence } \\
\text { model }\end{array}$ & CFD(Nm) & Exp. (Nm) & \%Error \\
\hline S-Allmaras & $\mathbf{3 3 1 . 8 6 1}$ & & $\underline{4.60}$ \\
\hline Standard k- $\varepsilon$ & $\mathbf{3 0 3 . 3 3 3}$ & & $\mathbf{5 . 3 4}$ \\
\hline RNG k- $\varepsilon$ & $\mathbf{3 4 5 . 4 3 5}$ & \multirow{3}{*}{$\mathbf{3 1 7 . 2 6}$} & $\mathbf{8 . 8 8}$ \\
\hline SST k- $\omega$ & $\mathbf{3 5 4 . 6 5 1}$ & & $\mathbf{1 1 . 7 9}$ \\
\hline
\end{tabular}

Table 2. Comparison of computed and measured torque results at wind speed at $10.56 \mathrm{~m} / \mathrm{s}$

\begin{tabular}{|c|c|c|c|}
\hline $\begin{array}{c}\text { Turbulence } \\
\text { model }\end{array}$ & CFD(Nm) & Exp. (Nm) & $\%$ Error \\
\hline S-Allmaras & 1036.394 & \multirow{4}{*}{1190.04} & 4.16 \\
\hline Standard k- $\varepsilon$ & 1157.725 & & 2.72 \\
\hline RNG k- $\varepsilon$ & 990.287 & & 16.79 \\
\hline 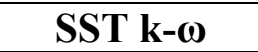 & 1039.332 & & 12.66 \\
\hline
\end{tabular}

Table1 indicated that in low wind speed, the Spalart-Allmaras turbulence model shows good agreement with experimental data because the Spalart-Allmaras model was designed 
specifically for aerospace applications involving wall-bounded flows and it has a good performance for boundary layers subjected to adverse pressure gradients [21]. In addition, the Spalart-Allmaras model is effectively a low-Reynolds-number model, requiring the viscosityaffected region of the boundary layer to be properly resolved. However, as shown in Table 2 in higher wind speeds standard k- $\varepsilon$ turbulence has better agreement and RNG k- $\varepsilon$, SST k- $\omega$ model has high deviation from experimental data in both high and low speed. Furthermore, Splart-Allmaras model has much better convergence and low computing cost compared to other models.

Figure 8. Shows the axial velocity distributions in the wake for Standard k- $\varepsilon$ turbulence model.

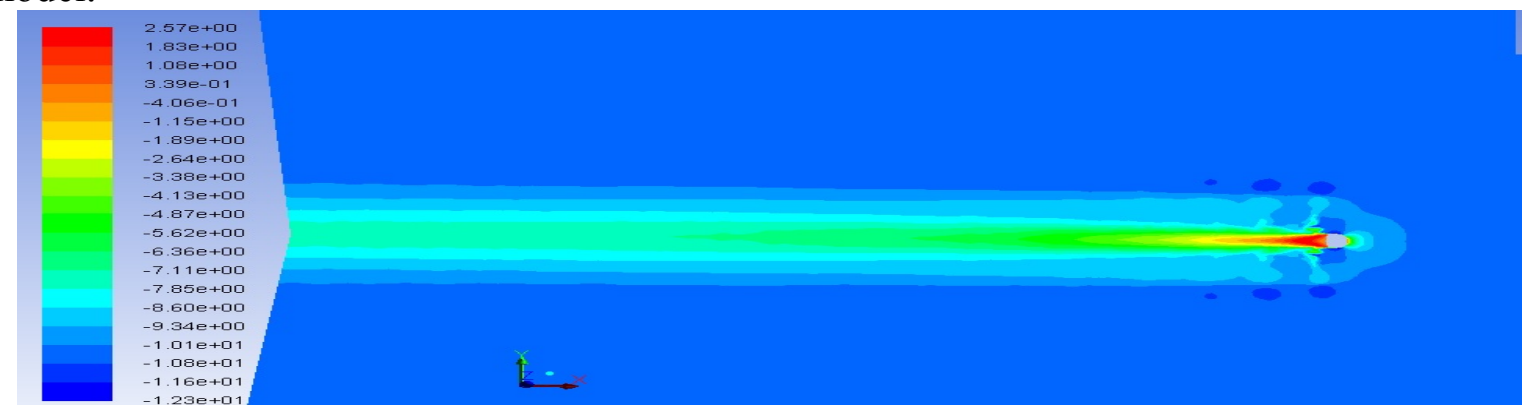

Figure 8.Contour of axial velocity distributions in wake sections along the flow direction for Standard $\mathrm{k}-\varepsilon$ turbulence model at $\mathrm{U}_{\infty}=10.56 \mathrm{~m} / \mathrm{s}$

\section{7-Conclusions and Future work}

The aerodynamic characteristics of a model HAWT were predicted by the Fluent. CFD simulations of HAWT blade were carried out and the evaluation of four turbulence models had been done to predict pressure coefficient and torque of horizontal axis wind turbine for two wind speeds. The numerical simulations also allow the prediction of the basic features of the wake development downwind the rotor and the simulation results were validated and assessed with experimental data.

An unstructured mesh with nearly 2 million gird points was used for the computations. Unstructured meshing approach allowed us to have some control on the grid resolution. However, comparing pressure predictions with experiments showed that a finer grid was required in the vicinity of the leading edge.

Computations were performed at $7.2 \mathrm{~m} / \mathrm{s}$ and $10.56 \mathrm{~m} / \mathrm{s}$ wind speeds. At the lower wind speed Spalart-Allmaras model gave better result whereas in high wind speed the standard k- $\varepsilon$ turbulence model had better agreement with experimental data. Unexpectedly, the RNG- k- $\varepsilon$ and SST k- $\omega$ model results were not good enough to predict HAWT torque accurately. Therefore, further research using advanced turbulence models is needed.

Reynolds Averaged Navier-Stokes (RANS) models are very limited in simulating the unsteady and 3-D nature of turbulence. Therefore, in future works, the CFD simulation of the wind turbine flow field with the large-eddy simulation (LES) approach will be performed in order to better simulate the flow separation and the 3-D wake flow field.

\section{References}

[1] Robinson, M.C., Simms, D.A., Hand, M.M., Schreck, S.J., Horizontal Axis Wind Turbine Aerodynamics: Three-Dimensional Unsteady and Separated Flow Influences, 3rd ASME/JSME Joint Fluids Engineering Conference, FEDSM99-S295-01, 1999.

[2] Burton, T., Sharpe, D., Jenkins, N., Bossanyi, E., Wind Energy Handbook, John-Wiley and Sons, 2001. 
[3] Hansen, M.O.L., Sorensen, J.N., Voutsinas, S., Sorensen, N., Madsen, H.Aa., State of the Art Wind Turbine Aerodynamics and Aeroelasticity, Progress in Aerospace Sciences, vol. 42, 2006, pp. $285-330$.

[4] Reese, H., Kato, C., Carolus, T.H., Large Eddy Simulation of Acoustical Sources in a Low Pressure Axial-Flow Fan Encountering Highly Turbulent Flow, ASME Journal of Fluids Engineering, vol. 129, 2007, pp. 263 - 272.

[5] Gorla, R.S.R., Khan, A.A., Turbomachinery: Design and Theory, Marcel Dekker, 2003.

[6] Jimenez, A., Crespo, A., Migoya, E., Garcia J., Advances in Large Eddy Simulation of a Wind Turbine Wake, Journal of Physics: Conference Series, vol. 75, 2007.

[7] Pope, S.B., Turbulent flow , Combridge University press, 2001.

[8] Wolfstein , M., Some Comments on Turbulence Modeling, International Jurnal of Heat and Mass Trensfer, vol.52,2009, pp.4103-4107

[9] Tony Burton,David Sharpe,Nick Jenkins,Ervin Bossanyi, Wind Energy Handbook, JOHN WILEY \& SONS, LTD, 2001.

[10] Martin O. L. Hansen, Aerodynamics of Wind Turbines, Second Edition, published by Earthscan in the UK and USA in 2008

[11] Jonkman JM. , Modeling of the UAE wind turbine for refinement of FASTAD, NREL/TP-500-34755. Colorado: National Renewable Energy Laboratory; Dec.ber 2003

[12] J. L. Tangier, NREL Airfoil Families for HAWTs, National Renewable Energy Laboratory 1617 Cole Boulevard Golden,Colorado 80401-3393, updated AWEA 1995.

[13] Hand, D.G. Infield, H.A. Madsen, R.J.H. Paynter and D.A. Simms, "Final report of IEA Annex XIV: field rotor aerodynamics”, ECNC-97-027, Energy Research Center of the Netherlands, 1997.

[14] D. Simms, S. Schreck, M. Hand and L. Fingersh, "NREL Unsteady Aerodynamics Experiment in the NASA-Ames Wind Tunnel: A Comparison of Predictions to Measurements", National Renewable Energy Laboratory, NREL/TP-500-29494, 2001.

[15] J.C. Tannehill, D.A. Anderson and RH. Pletcher, "Computational Mechanics and Heat Transfer". Taylor \& Francis Inc., NY, 2nd ed.,1997.

[16] Fluent Inc., Fluent 6.2 Documentation-User's Guide, 2004.

[17] P.R. Spalart and S.R. Allmaras, "A one-equation turbulence model for aerodynamic flows", Technical Report AIAA-92-0439,American Institute of Aeronautics and Astronautics, 1992.

[18] D.C Wilcox, "Turbulence modelling for CFD”. DCW Industries Inc., 2nd ed., 1998.

[19] David Hartwanger* and Dr Andrej Horvat ,3D MODELLING OF A WIND TURBINE USING CFD, NAFEMS Conference 2008, United Kingdom

[20] Chalothorn T. and Tawit Ch., Optimal Pitch for Untwisted Blade Horizontal Axis Wind Turbine, 21-23 November 2006, Bangkok, Thailand

[21] Kamyar M., M. Y.et.al.(July 2011) Effects of turbulence model in computational fluid dynamics of horizontal axis wind turbine aerodynamic, Amirkabir University of Technology Hafez Avenue, Tehran, 15875-4413 IRAN

[22] Abhishek G. R., Saskatchewan J.et.al.( 2007),Prediction of aerodynamic forces on wind turbine blades using computational fluid dynamics, Gupta, Abhishek, Canada

[23] Armen S.et.al.( Dec. 2010), SIMULATION AND MODELING OF FLOW FIELD AROUND A HORIZONTAL AXIS WIND TURBINE (HAWT) USING RANS METHOD Florida Atlantic University, Boca Raton, Florida.

[24] N.S. Tachos,, A.E. Filios2, D.P. Margaris1 and J.K. Kaldellis.(2009) A Computational Aerodynamics Simulation of the NREL Phase II Rotor University of Patras, GR-265 04 Patras, Greece 